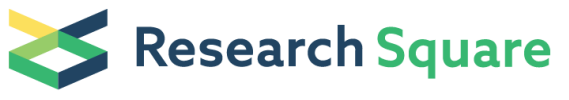 \\ Preprints are preliminary reports that have not undergone peer review. \\ They should not be considered conclusive, used to inform clinical practice, or referenced by the media as validated information.
}

\section{Desmoplastic Small Round Cell Tumor of the Head and Neck: A Clinicopathological, Immunohistochemical and Molecular Analysis of Three Cases with Literature Review}

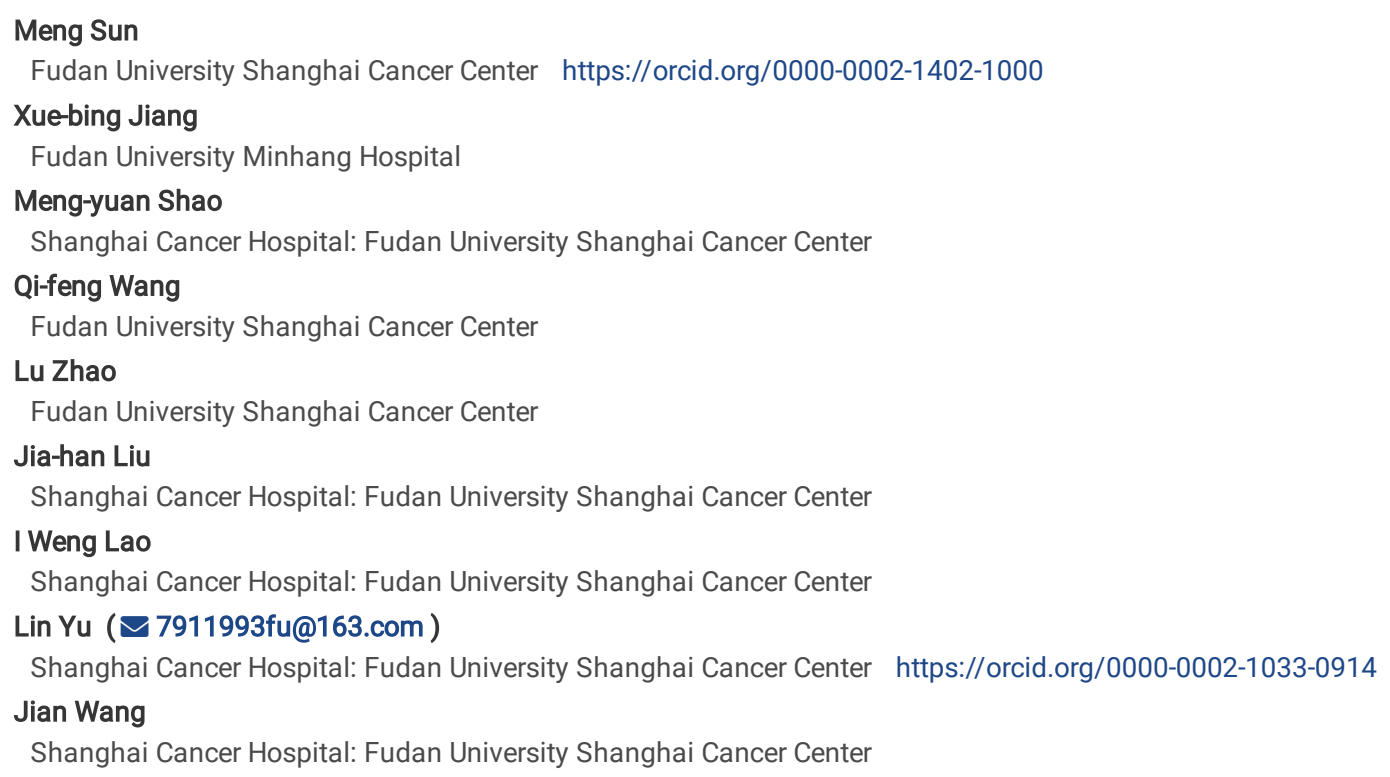




\section{Abstract}

Background: Desmoplastic small round cell tumor (DSRCT) is a rare aggressive malignancy typically originating from the abdominal or pelvic cavity. DSRCT presenting as a primary head and neck tumor has rarely been described in the literature.

Case presentation: We present three cases of DSRCT arising in the head and neck to further characterize its clinicopathological features. All three patients were male and aged 36,30 and 17 years. The involved sites included the orbit ( 1 case) and submandibular gland ( 2 cases). The tumors ranged in size from 2.4 to $3.5 \mathrm{~cm}$ (mean, $2.1 \mathrm{~cm}$ ). Histologically, all tumors showed irregular-shaped, variable-sized nests of small round cells deposited in an abundant desmoplastic stroma. Tumor cells contained small hyperchromatic nuclei and scant amounts of eosinophilic cytoplasm with inconspicuous nucleoli. Immunohistochemically, the tumors were positive for AE1/AE3 (3/3), desmin (3/3), vimentin (2/2), NSE (1/1) and EMA (1/1). Fluorescence in situ hybridization (FISH) analysis demonstrated the presence of EWSR1 and WT1 rearrangements in all three cases. All patients received surgery and adjuvant chemotherapy and/or radiotherapy. There was no evidence of recurrence and metastasis in two patients, and the third suffered lung metastasis.

Conclusions: DSRCT arising in the head and neck represents an extremely rare condition. It is easily mistaken as poorly differentiated carcinoma due to similar morphology and expression of epithelial markers. Immunohistochemistry assay in conjunction with molecular detection of EWSR1-WT1 fusion will be helpful for arriving at an accurate diagnosis to avoid misdiagnosis and inappropriate treatment.

\section{Background}

Desmoplastic small round cell tumor (DSRCT) is an extremely rare malignant tumor that commonly manifests as an intra-abdominal or pelvic mass with a predilection for young males. It typically shows co-expresssion of epithelial, mesenchymal and neural markers and harbors a characteristic $t$ (11; 22) ( 13 ; q12) translocation resulting a specific EWSR1-WT1 fusion gene transcript [1, 2]. Extra-abdominal involvements, such as central nervous system, mediastinum, pleura, lung, paratesticular region, bone and soft tissue, are very uncommon, comprising less than $5 \%$ of DSRCT [1, 2, 4-6, 8]. Manifestations in the head and neck are even more rare. To date, only 22 patients diagnosed with DSRCT have been reported in the English literature [3, 6-22, 24-26]. Due to its rarity and unexpected occurrence in the head and neck, DSRCT is likely to be misdiagnosed as other malignancies by clinicians and pathologists. Herein, we present three additional cases of DSRCT arising in the head and neck to enhance the recognition of its clinicopathological features and avoid diagnostic and therapeutic pitfalls.

\section{Case Presentation Clinical findings}

\section{Case 1}

A 36-year-old male presented with vision decline in the right eye accompanied by difficulty in opening for more than one month. B-ultrasound showed a welldefined solid mass with uneven internal echoes on the posterior pole of the right orbit, measuring approximately $22.2 \times 20.7 \mathrm{~mm}$. A Computed tomography (CT) scan revealed an ovoid, well-circumscribed soft tissue mass of the right orbital roof, with slightly enhancement, measuring approximately $2.4 \times 2.1 \times 1.6 \mathrm{~cm}$ in size (Fig. 1a). Magnetic resonance imaging (MRI) displayed a solid heterogeneous mass in the right orbital roof (Fig. 1b). Then, the patient was treated with a local excision of the tumor. The referring diagnosis was poorly differentiated carcinoma. To confirm the diagnosis, the pathological materials were sent to our department for further consideration. After re-evaluation of the H\&E slides with application of immunohistochemistry and FISH analysis, the diagnosis of DSRCT was finally rendered. The patient received postoperative chemotherapy and radiotherapy. There was no evidence of recurrence or metastasis 14 months after surgery.

\section{Case 2}

A 30-year-old man went to the clinic of a local hospital because of the left submandibular gland mass for several months. After admission, the patient underwent a complete excision of the mass soon. Intraoperatively, two masses were identified, measuring approximately $3.5 \times 3.8 \times 2.5 \mathrm{~cm}$ and $1 \times 0.8 \times 0.6 \mathrm{~cm}$, respectively. The lesion was considered as poorly differentiated carcinoma with neuroendocrine differentiation by the referring pathologist. After surgery, the patient was treated with an adjuvant chemotherapy. Unfortunately, a CT scan revealed multiple metastatic nodules in bilateral lungs 5 months later. Then, the patient came to our department for further diagnosis. With the adjunctive study of immunohistochemistry and FISH, the lesion was re-diagnosed as DSRCT.

\section{Case 3}

A 17-year-old man complained of a slowly enlarging and painless mass of the left submaxilla for more than one year. Physical examination revealed a welldefined solid mass with no tenderness on the left submandibular gland, measuring approximately $2.5 \times 2 \mathrm{~cm}$. MRI showed a solid homogeneous mass of the left submandibular gland, suspicious of lymphoma or mixed tumor. Subsequently, the patient underwent a complete excision of the tumor. The referring pathologist suggested a diagnosis of poorly differentiated squamous cell carcinoma. Tissue sections were sent to our department and finally diagnosed as DSRCT. Then, the patient received an adjuvant chemotherapy. There was no evidence of recurrence or metastasis 8 months after surgery.

\section{Pathological Features}

Grossly, all specimens presented multinodular masses ranging from 2.4 to $3.5 \mathrm{~cm}$ in maximum diameter (mean, $2.1 \mathrm{~cm}$ ). On cut section, all three tumors were solid and firm in consistency and grayish-white in color. Histologically, all three lesions showed similar morphological features, which consisted of small 
round, oval cells with uniform morphology embedded in an abundant desmoplastic stroma (Fig. 2a). Tumor cells were arranged in small clumps, large nests, trabeculas or cord-like pattern (Fig. 2b, 2c), possessing hyperchromatic nuclei with unclear nucleoli and pale eosinophilic cytoplasm with indistinct margin

(Fig. 2d). The mitotic figures were easily identified. The desmoplastic stroma was composed of spindle cells mimicking fibroblasts/myofibroblasts, accompanied by hyaline degeneration and vascular proliferation in some areas. Case 2 extensively infiltrated the peripheral nerves. The tumor showed lymph node metastasis in case 3.

\section{Immunohistochemical And Molecular Findings}

Immunohistochemically, the tumors showed positivity for AE1/AE3 (3/3) (Fig. 3a), desmin (3/3), vimentin (2/2), CD99 (2/2), Syn (1/3), NSE (1/1), EMA (1/1) (Fig. 3b) and INI-1 (1/1). Besides, desmin and vimentin displayed a paranuclear cytoplasmic dot-like positivity pattern (Fig. 3c,3d). Other markers, including WT1, ERG, Fli-1, MyoD1, myogenin, CgA, CD56 and TTF-1, were all negative. The Ki-67 index was 40\% 50\%.

By FISH assay, all three cases showed the presence of EWSR1 (Fig. 4a) and WT1 (Fig. 4b) rearrangements.

\section{Discussion}

Desmoplastic small round cell tumor is a unique mesenchymal neoplasm with distinct histological features and multiphenotypic differentiation, which was first described by Gerald and Rosai in 1989 [23]. It is a highly aggressive tumor with a predilection for adolescent males and occurs predominantly in the abdominal and pelvic cavity. Isolated cases of extra-abdominal involvement have been reported in the central nervous system, mediastinum, pleura, lung, paratesticular region, bone and soft tissue $[1,2,4-6]$. The presentation of DSRCT as a primary head and neck lesion is even extremely rare. To our knowledge, only 22 cases have been documented in previous literatures [3,6-22, 24-26]. In this study, we present a small series of three additional cases of DSRCT in the head and neck, increasing the reported number to 25 . The clinicopathological features of 25 cases are summarized in Table 1 . Like classic intra-abdominal DSRCT, DSRCT of the head and neck also occurred in the second to third decade of lifetime, with a mean and median age of 26 and 25 years (range, 4 to 61 years), respectively. Compared with intra-abdominal DSRCT (male:female, 5:1) [11, 27], there was a more prominent male predilection with a male to female ratio of 24: 1 . Tumors arose in the salivary glands ( 8 cases), brain (4 cases), orbital region (4 cases), sinonasal region (4 cases), cranium ( 3 cases), middle ear ( 1 case) and neck region ( 1 case). The tumor size (available in 17 cases) ranged from 1.5 to $8 \mathrm{~cm}$ in maximum diameter (mean, $4.1 \mathrm{~cm}$ ). Clinically, most tumors presented as a slowly enlarging mass or swelling of soft tissue, occasionally with pain. The specific symptoms and signs of DSRCT depend on the tumor location and involved organs or tissues $[6,11,13,14,17,18,22]$.

Histologically, most DSRCTs are typically characterized by sharply demarcated nests or sheets of varying size with small round or oval cells embedded in a hypervascular desmoplastic stroma. In some cases, the tumor cells may be arranged in large nests with central necrosis, tubular-like structures, trabeculas, and cord-like patterns. Other unusual features, including Homer Wright-like rosettes, papillary areas, zones that resemble transitional cell carcinoma, and myxoid background, can also be identified occasionally [2, 27, 28]. In addition, tumor cells may also show rhabdoid, spindled, pleomorphic, vacuolated, signetring or larger cell morphology $[28,30]$. Rare cases simply consist of solid sheets of round cells without desmoplastic stroma, making identification of this rare tumor even more difficult.

DSRCT has a distinctive immunohistochemical feature. The tumor displays multiphenotypic differentiation with co-expression of epithelial (cytokeratins, EMA), mesenchymal (desmin, vimentin) and neural markers (NSE). Of note, typical examples of DSRCT usually demonstrate a unique paranuclear cytoplasmic dot-like staining pattern of desmin and vimentin. The reported cases of DSRCT in the head and neck showed variable expression of cytokeratin $(95.7 \%, 22 / 23), \operatorname{EMA}(70.6 \%, 12 / 17)$, desmin $(91.7 \%, 22 / 24)$, vimentin $(100 \%, 17 / 17)$ and NSE $(76.2 \%, 16 / 21)$, which is almost in line with intraabdominal tumors [28, 31, 32]. More than $95 \%$ of DSRCTs harbor a unique cytogenetic abnormality, t $(11 ; 22)(p 13$; q12), which fuses the amino terminus of EWSR1 gene on $22 q 12$ to the carboxy terminus of WT1 on 11 p13 [33,34]. All tested cases $(20 / 20,100 \%)$ of DSRCT in the head and neck possessed EWSR1-WT1 gene translocation. Besides, immunohistochemistry for WT1 amino terminus and carboxy terminus antibodies may be useful to identify EWSR1-WT1 transcript despite the presence of some controversies regarding the epitope specificity of WT1 antibody used [37]. Most of previous studies revealed that DSRCT showed nuclear expression of WT1 antibody (Clone:C-19) to the carboxy terminus with positive rates $70 \%$ 100\%, but no expression of WT1 antibody

(Clone:6F-H2) to amino terminus [21, 31, 37]. In this series, three cases were also negative for WT1 amino terminus antibody. However, two other studies reported that DSRCT displayed discrete nuclear or paranuclear cytoplasmic staining of WT1 antibody to the amino terminus, with positive rates of $91 \%$ $(29 / 32)$ and $81.4 \%(22 / 27)$, respectively $[3,28]$. Murphy et al. have identified that some cases have novel fusion transcripts or express full-length WT1, resulting in nuclear staining for WT1 N-terminal antibody; and they have proposed that fusion transcripts in DSRCT result in the altered immunostaining pattern for WT1[37]. Hence, interpretation of WT1 immunostaining requires knowledge of antibody target epitopes and correlation with results of molecular testing for the EWS-WT1 fusion transcript. Among DSRCT of the head and neck, 50\% (6/12) of cases were immunoreactive for WT1. However, the antibody type and immunostaining pattern were less uncertain in most cases, because these cases were mainly from isolated case reports or small series.

The histogenesis of DSRCT is still uncertain owing to few studies focused on it in the literature. Originally, DSRCT was speculated to derive from mesothelial or submesothelial cells, given that it mainly occurs in the mesothelial-lined cavities and expresses both epithelial and mesenchymal antigens [3]. However, some tumors arising in locations not lined by mesothelial cells challenged this hypothesis. Furthermore, there is no ultrastructural features of mesothelial differentiation in DSRCT [32,36], which also does not support the above viewpoint. Therefore, the issue of origin of DSRCT remains to be studied.

The main differential diagnosis of DSRCT embraces a variety of malignancies with small round cell morphology, especially poorly differentiated carcinoma (including neuroendocrine carcinoma), Ewing's sarcoma (EWS) and alveolar rhabdomyosarcoma (ARMS). Due to the uncommon tumor site as well as similar histologic features and expression of epithelial markers, all three cases in this series were initially misdiagnosed as poorly differentiated carcinoma by the 
referring pathologists. But different from DSRCT, poorly differentiated carcinoma often lacks prominent desmoplastic stroma and expression of desmin. Moreover, it is also absent of EWSR1-WT1 fusion. In addition, EWS also needs to be differentiated from DSRCT, because both tumors have overlapping immunophenotype and cytogenetic features. However, EWS is generally positive for CD99 (membrane staining) and NKX2.2 [38], but usually negative for AE1/AE3 and desmin. The unique $t(11 ; 22)$ (p13; q12) chromosomal translocation of DSRCT occurs at breakpoints different from that of EWS $t$ (11; 22) (q24; q12) resulting in EWSR1-FLI1 fusion [34]. Finally, ARMS can be confused with DSRCT. The application of myogenic markers of myogenin and MyoD1 is helpful in the separation of DSRCT from ARMS; again, the detection of FOX01 translocation by FISH can also distinguish these two entities. Other small round cell tumors occurring in the head and neck may also enter into the differential diagnosis of DSRCT, such as malignant melanoma and neuroblastoma. The positive staining of melanotyic markers in melanoma, including S100 protein, SOX10, HMB-45 and Melan-A, helps to distinguish from DSRCT. Although neuroblastoma and DSRCT are both positive for NSE, neuroblastoma is usually negative for EMA and desmin. It is worth noting that abdominal DSRCT can develop metastases to the head and neck region occasionally [39]. In such settings, the detailed medical history and careful clinical examinations are warranted in the distinction. All three patients reported in this study had no special clinical history.

So far, the treatment of DSRCT remains challenging. Despite a combined therapeutic strategy of surgery, radiotherapy and chemotherapy applied, the overall prognosis remains very poor, with approximately $29 \%$ for a 3-year survival and just $18 \%$ for a 5 -year survival [7], respectively. Recently, some reports revealed that patients treated with aggressive surgery and intense alkylator therapy (P6 protocol: vincristine, doxorubicin, cyclophosphamide, ifosfamide and etoposide) had a better prognosis [8]. Besides, patients with superficial DSRCT also have a better outcome, because earlier clinical manifestations and symptoms offer a higher chance of complete surgical excision [14]. Among DSRCT of the head and neck, 6 of 22 (27.3\%) patients with follow-up information died, with five cases dead of the disease and one dead of other causes. Two patients were alive with disease, and the other 14 remained well with no evidence of disease. Due to the limited follow-up duration, the prognosis of DSRCT in the head and neck is difficult to compare with that of intra-abdominal DSRCT. Therefore, whether there is a difference in the prognosis between the two subsets still need to be elucidated in the future.

In summary, we describe three cases of extra-abdominal DSRCT arising primarily in the head and neck. Due to the unexpected occurrence of DSRCT in this unusual site and similar histological and/or immunohistochemical features, it may be easily misinterpreted as other small round cell tumors, especially poorly differentiated carcinoma (including neuroendocrine carcinoma). This study further demonstrates the importance of including DSRCT into the differential diagnosis of small round cell tumors of the head and neck, particularly those affecting the young patients and expressing of epithelial markers. In challenging cases, molecular assays of EWSR1-WT1 fusion by RT-PCR, FISH or next-generation sequencing will be helpful for establishing a correct diagnosis.

\section{Abbreviations}

DSRCT, desmoplastic small round cell tumor; MRI, magnetic resonance imaging; CT, computed tomography; EWS, Ewing's sarcoma; ARMS, alveolar rhabdomyosarcoma; H\&E, hematoxylin-and-eosin; EMA, epithelial membrane antigen; NSE, neuron specific enolase; FISH, fluorescence in situ hybridization; RT$\mathrm{PCR}$, reverse transcription-polymerase chain reaction.

\section{Declarations}

\section{Ethics approval and consent to participate}

This study was granted an exemption from requiring ethics approval from the Medical

Ethics Committee of Fudan University Shanghai Cancer Center.

\section{Consent for publication}

Written informed consent was obtained from the patient for publication of this case report and any accompanying images. A copy of the written consent is available for review by the Editor of this journal.

\section{Availability of data and materials}

The dataset supporting the conclusions of this article is included within the article (Table 1).

\section{Competing interests}

The authors declare that they have no competing interests.

\section{Funding}

This study was supported by Shanghai Municipal Natural Science Foundation (Grant No: 18ZR1407300), Shanghai Science and Technology Development Fund

(19MC1911000) and Shanghai Municipal Key Clinical Specialty(shslczdzk01301).

\section{Authors' contributions}

SM drafted the manuscript; JXB and SMY collected clinical and follow-up data of three cases; JXB contributed equally to this work with SM, and is the co-first 
author for this paper. WQF, ZL, LJH and LIW participated in histological diagnosis and immunohistochemical evaluation; Wang $\mathrm{J}$ and Yu L participated in histological diagnosis and proofread the paper. All authors read and approved the final manuscript.

\section{Acknowledgement}

The authors would like to thank Xue-Ke Zhou and Xu Cai for technical assistance

\section{References}

1. The WHO Classification of Tumours Editorial Board. WHO Classification of Tumours Soft Tissue and Bone Tumours. 5th ed. Lyon: IARC Press; 2020.

2. Goldblum J, Weiss S. Folpe. A L. Enzinger \& Weiss's Soft Tissue Tumors. 7th ed.: Elsevier; 2020.

3. Lae ME, Roche PC, Jin L, Lloyd RV, Nascimento AG. Desmoplastic small round cell tumor: a clinicopathologic, immunohistochemical, and molecular study of 32 tumors. Am J Surg Pathol. 2002;26:823-35.

4. Ryan A, Razak A, Graham J, Benson A, Rowe D, Haugk B, Verrill M. Desmoplastic small round-cell tumor of the pancreas. J Clin Oncol. 2007;25:1440-2.

5. Karavitakis EM, Moschovi M, Stefanaki K, Karamolegou K, Dimitriadis E, Pandis N, Karakousis CP, Tzortzatou-Stathopoulou F. Desmoplastic small round cell tumor of the pleura. Pediatr Blood Cancer. 2007;49:335-8.

6. Thondam SK, Plessis DD, Cuthbertson DJ, Das KSV, Javadpour M, MacFarlane IA, Leggate J, Haylock B, Daousi C. Intracranial desmoplastic small round cell tumor presenting as a suprasellar mass. J Neurosurg. 2015;122:773-7.

7. Xu J, Yao M, Yang X, Liu T, Wang S, Ma D, Li X. Desmoplastic small round cell tumor of the middle ear: A case report. Med (Baltim). 2018;97:e0494.

8. He XR, Liu Z, Wei J, Li WJ, Liu T. Primary desmoplastic small round cell tumor in the left orbit: a case report and literature review. Int Ophthalmol. 2019;39:471-5.

9. Hu CY, Wang SY. Clinicopathological features of sinonasal desmoplastic small round cell tumor: I additional case and 2 cases of literature review. Fudan University Journal of Medical Sciences. 2007;1:87-92.

10. Bengu CH, Hanna EY, Bell D, Esmaeli B. Desmoplastic Small Round Cell Tumor Presenting as an Ocular Mass: Unusual Localization and Remarkable Surgical Approach. Curr Oncol Rep. 2017;19:80.

11. Khachaturov V, Christopher RW, Hodge JR, Doyle JJ, Leitao DJ, Stefanovici C, Fritchie K. Primary intraosseous desmoplastic small round cell tumor of the calvarium: Case report and review of the literature. Human Pathology: Case Reports. 2015;2:9-15.

12. López F, Costales M, Vivanco B, Fresno MF, Suárez C, Llorente JL. Sinonasal desmoplastic small round cell tumor. Auris Nasus Larynx. 2013;40:573-6.

13. Pang B, Leong CC, Salto-Tellez M, Petersson F. Desmoplastic small round cell tumor of major salivary glands: report of 1 case and a review of the literature. Appl Immunohistochem Mol Morphol. 2011;19:70-5.

14. Yin WH, Guo SP, Yang HY, Chan JK. Desmoplastic small round cell tumor of the submandibular gland-a rare but distinctive primary salivary gland neoplasm. Hum Pathol. 2010;41:438-42.

15. Serhan Ku Peli MMKC, Arzu Sungur MZAA. Desmoplastic Small Round Cell Tumor of the Mandible in a Child with Unusual Plantar Metastasis. J Pediatr Hematol Oncol. 2010;32:155-7.

16. Rekhi BBRDS. At $(11 ; 22)$ (p13; q12) EWS-WT 1 positive desmoplastic small round cell tumor of the maxilla: An unusual case indicating the role of molecular diagnosis in round cell sarcomas. Journal of postgraduate medicine (Bombay). 2010;56: 201-205.

17. Neder L, Scheithauer BW, Turel KE, Arnesen MA, Ketterling RP, Jin L, Moynihan TJ, Giannini C, Meyer FB. Desmoplastic small round cell tumor of the central nervous system: report of two cases and review of the literature. Virchows Arch. 2009;454:431-9.

18. Santos GP, Gomez GJ, Batuecas CA, Flores CM, Sanchez GF. Small round cell desmoplastic tumour. Atypical morphology in the sub-maxillary gland. Acta Otorrinolaringol Esp. 2009;60:141-3.

19. Cho K, Ro JY, Choi J, Choi S, Nam SY, Kim SY. Mesenchymal neoplasms of the major salivary glands: clinicopathological features of 18 cases. Eur Arch Otorhinolaryngol. 2008;265:47-56.

20. Finke NM, Lae ME, Lloyd RV, Gehani SK, Nascimento AG. Sinonasal desmoplastic small round cell tumor: a case report. Am J Surg Pathol. 2002;26:799803.

21. Hill DA, Pfeifer JD, Marley EF, Dehner LP, Humphrey PA, Zhu X, Swanson PE. WT1 staining reliably differentiates desmoplastic small round cell tumor from Ewing sarcoma/primitive neuroectodermal tumor. An immunohistochemical and molecular diagnostic study. Am J Clin Pathol. 2002;114:345-53.

22. Wolf AN, Ladanyi M, Paull G, Blaugrund JE, Westra WH. The expanding clinical spectrum of desmoplastic small round-cell tumor: A report of two cases with molecular confirmation. Hum Pathol. 1999;30:430-5.

23. Gerald WL, Rosai J. Case 2. Desmoplastic small cell tumor with divergent differentiation. Pediatr Pathol. 1989;9:177-83.

24. Faras F, Abo-Alhassan F, Hussain AH, Sebire NJ, Al-Terki AE. Primary desmoplastic small round cell tumor of upper cervical lymph nodes. Oral Surgery, Oral Medicine, Oral Pathology and Oral Radiology. 2015;120: e4-e10.

25. Yoon M, Desai K, Fulton R, Bucci K, Russin M, Conway RM, O'Brien JM. Desmoplastic small round cell tumor: a potentially lethal neoplasm manifesting in the orbit with associated visual symptoms. Arch Ophthalmol. 2005;123:565-7.

26. Tison V, Cerasoli S, Morigi F, Ladanyi M, Gerald WL, Rosai J. Intracranial desmoplastic small-cell tumor. Report of a case. Am J Surg Pathol. 1996;20:1127. 
27. Lae ME, Roche PC, Jin L, Lloyd RV, Nascimento AG. Desmoplastic small round cell tumor: a clinicopathologic, immunohistochemical, and molecular study of 32 tumors. Am J Surg Pathol. 2002;26:823-35.

28. Rekhi B, Ahmed S, Basak R, Qureshi SS, Desai SS, Ramadwar M, Desai SB, Kurkure P, Jambhekar NA. Desmoplastic Small Round Cell TumorClinicopathological Spectrum, Including Unusual Features and Immunohistochemical Analysis of 45 Tumors Diagnosed at a Tertiary Cancer Referral Centre, with Molecular Results t $(11 ; 22)$ (p13; q12) (EWS-WT1) in Select Cases. Pathology Oncology Research. 2012;18:917-27.

29. Zhang W, Li C, Liu Q, Hu Y, Cao Y, Huang J. CT, MRI, and FDG-PET/CT imaging findings of abdominopelvic desmoplastic small round cell tumors: Correlation with histopathologic findings. Eur J Radiol. 2011;80:269-73.

30. Tison V, Cerasoli S, Morigi F, et al. Intracranial desmoplastic small-cell tumor. Report of a case. Am J Surg Pathol. 1996;20:112-7.

31. Zhang PJ, Goldblum JR, Pawel BR, Fisher C, Pasha TL, Barr FG. Immunophenotype of Desmoplastic Small Round Cell Tumors as Detected in Cases with EWS-WT1 Gene Fusion Product. Mod Pathol. 2003;16:229-35.

32. Ordonez NG. Desmoplastic small round cell tumor: II: an ultrastructural and immunohistochemical study with emphasis on new immunohistochemical markers. Am J Surg Pathol. 1998;22:1314-27.

33. Ferreira EN, Barros BDF, de Souza JE, et al. A genomic case study of desmoplastic small round cell tumor: comprehensive analysis reveals insights into potential therapeutic targets and development of a monitoring tool for a rare and aggressive disease. Human Genomics. 2016;10:36.

34. Fisher C. The diversity of soft tissue tumours with EWSR1 gene rearrangements: a review. Histopathology. 2014;64:134-50.

35. Ofori E, Ramai D, Nigar S, Xiao P, Shahzad G, Reddy M. (2017) Desmoplastic Small Round Cell Tumor: A Rare Case of Extraluminal Bowel Obstruction and Review of the Literature. J Gastrointest Cancer. 2019; 50: 560-563.

36. Lee Y, Hsiao C. Desmoplastic Small Round Cell Tumor: A Clinicopathologic, Immunohistochemical and Molecular Study of Four Patients. J Formos Med Assoc. 2007;106:854-60.

37. Murphy AJ, Bishop K, Pereira C, et al. A new molecular variant of desmoplastic small round cell tumor: significance of WT1 immunostaining in this entity. Hum Pathol. 2008;39(12):1763-70.

38. Hung YP, Fletcher CDM, Hornick JL. Evaluation of NKX2-2 expression in round cell sarcomas and other tumors with EWSR1 rearrangement: imperfect specificity for Ewing sarcoma. Modern Pathol. 2016;29(4):370-80.

39. Mihok NA, Cha I. Desmoplastic small round cell tumor presenting as a neck mass: a case report. Diagn Cytopathol. 2001;25(1):68-72.

\section{Tables}


Table 1

Clinicopathological Data of 25 Cases of DSRCT arising in the head and neck

\begin{tabular}{|c|c|c|c|c|c|c|c|c|c|c|c|c|}
\hline \multirow[t]{2}{*}{$\begin{array}{l}\text { Case } \\
\text { No. }\end{array}$} & \multirow[t]{2}{*}{ Source } & \multirow[t]{2}{*}{ Age(years) } & \multirow[t]{2}{*}{ Sex } & \multirow[t]{2}{*}{ Location } & \multirow[t]{2}{*}{ Symptom } & \multirow[t]{2}{*}{$\begin{array}{l}\text { Size } \\
(\mathrm{cm})\end{array}$} & \multicolumn{2}{|c|}{$\begin{array}{l}\text { EWSR1- } \\
\text { WT1 }\end{array}$} & \multirow[t]{2}{*}{$\begin{array}{l}\text { WT1 } \\
\text { (IHC) }\end{array}$} & \multirow[t]{2}{*}{ Treatment } & \multirow[t]{2}{*}{ Metastasis } & \multirow{2}{*}{$\begin{array}{l}\text { Recurrence } \\
\text { (months) }\end{array}$} \\
\hline & & & & & & & $\begin{array}{l}\text { RT- } \\
\text { PCR }\end{array}$ & FISH & & & & \\
\hline 1 & $\begin{array}{l}\text { He XR et al. } \\
(2018)\end{array}$ & 16 & M & Left orbit & $\begin{array}{l}\text { Pain swelling } \\
\text { and a palpable } \\
\text { nodule }\end{array}$ & 1.5 & / & $(+)$ & / & Surgery & $\mathrm{N}$ & $\mathrm{N}$ \\
\hline 2 & $\begin{array}{l}\text { Xu J et al. } \\
(2018)\end{array}$ & 59 & M & Right middle ear & $\begin{array}{l}\text { Hearing loss, } \\
\text { tinnitus and } \\
\text { recurrent } \\
\text { headache }\end{array}$ & NA & / & / & / & $\begin{array}{l}\text { Surgery, } \\
\text { CT and } \\
\text { RT }\end{array}$ & $\mathrm{N}$ & $\mathrm{N}$ \\
\hline 3 & $\begin{array}{l}\text { Bengu CH et } \\
\text { al. (2017) }\end{array}$ & 4 & M & Right orbit & $\begin{array}{l}\text { Swelling and } \\
\text { ptosis }\end{array}$ & 3.2 & / & / & $(+)$ & $\begin{array}{l}\text { Surgery, } \\
\text { CT and } \\
\text { RT }\end{array}$ & $\mathrm{N}$ & $\mathrm{N}$ \\
\hline 4 & $\begin{array}{l}\text { Hu CY et al. } \\
(2017)\end{array}$ & 47 & M & Maxillary sinus & Epistaxis & 4.1 & / & $(+)$ & / & $\begin{array}{l}\text { Surgery, } \\
\text { CT and } \\
\text { RT }\end{array}$ & $\mathrm{N}$ & $Y, 4$ \\
\hline 5 & $\begin{array}{l}\text { Khachaturov } \\
\text { V et al. } \\
\text { (2015) }\end{array}$ & 6 & M & Calvarium & $\begin{array}{l}\text { Right anterior } \\
\text { ear pain and } \\
\text { swelling }\end{array}$ & NA & $(+)$ & / & $(-)$ & $\begin{array}{l}\text { CT and } \\
\text { RT }\end{array}$ & $\mathrm{N}$ & $\mathrm{N}$ \\
\hline 6 & $\begin{array}{l}\text { Thondam } \\
\text { SK et al. } \\
\text { (2015) }\end{array}$ & 27 & M & Suprasellar & $\begin{array}{l}\text { Frontal } \\
\text { headaches, } \\
\text { drowsiness, } \\
\text { and bitemporal } \\
\text { hemianopia }\end{array}$ & NA & $(+)$ & $(+)$ & $(-)$ & $\begin{array}{l}\text { Surgery, } \\
\text { CT and } \\
\text { RT }\end{array}$ & $\mathrm{Y}$ & $Y, 4$ \\
\hline 7 & $\begin{array}{l}\text { Faras F et } \\
\text { al. (2015) }\end{array}$ & 11 & M & $\begin{array}{l}\text { Left upper } \\
\text { Cervical region }\end{array}$ & $\begin{array}{l}\text { A left neck } \\
\text { mass }\end{array}$ & 4.0 & $(+)$ & $(+)$ & $(+)$ & $\begin{array}{l}\text { Surgery, } \\
\text { CT and } \\
\text { RT }\end{array}$ & $\mathrm{N}$ & $\mathrm{N}$ \\
\hline 8 & $\begin{array}{l}\text { López F et } \\
\text { al. (2013) }\end{array}$ & 61 & M & $\begin{array}{l}\text { Right ethmoid } \\
\text { sinus }\end{array}$ & $\begin{array}{l}\text { Respiratory } \\
\text { insufficiency } \\
\text { and } \\
\text { nosebleeds }\end{array}$ & 8 & $(+)$ & $(+)$ & $(-)$ & $\begin{array}{l}\text { Surgery } \\
\text { and RT }\end{array}$ & $\mathrm{N}$ & $\mathrm{N}$ \\
\hline 9 & $\begin{array}{l}\text { Pang B et al. } \\
(2011)\end{array}$ & 41 & M & $\begin{array}{l}\text { Left } \\
\text { submandibular } \\
\text { gland }\end{array}$ & I & 5 & $(+)$ & $(+)$ & $(+)$ & Surgery & Y & $\mathrm{N}$ \\
\hline 10 & $\begin{array}{l}\text { Rekhi B et } \\
\text { al. (2010) }\end{array}$ & 25 & M & $\begin{array}{l}\text { Left maxillary } \\
\text { sinus }\end{array}$ & $\begin{array}{l}\text { Left sided } \\
\text { nasal blockage } \\
\text { and } \\
\text { intermittent } \\
\text { bloody nasal } \\
\text { discharge }\end{array}$ & 4.5 & / & / & $(-)$ & $\begin{array}{l}\text { Surgery, } \\
\text { CT and } \\
\text { RT }\end{array}$ & $\mathrm{N}$ & $Y, 3$ \\
\hline 11 & $\begin{array}{l}\text { Küpeli S et } \\
\text { al. (2010) }\end{array}$ & 16 & M & Left Mandible & $\begin{array}{l}\text { Tough swelling } \\
\text { on the left side } \\
\text { of his face }\end{array}$ & NA & / & / & / & $\begin{array}{l}\text { CT and } \\
\text { RT }\end{array}$ & $\mathrm{Y}$ & $\mathrm{N}$ \\
\hline 12 & $\begin{array}{l}\text { Neder L et } \\
\text { al. (2009) }\end{array}$ & 37 & M & $\begin{array}{l}\text { Cerebellopontine } \\
\text { angle }\end{array}$ & $\begin{array}{l}\text { Left-sided } \\
\text { hearing loss } \\
\text { and tinnitus }\end{array}$ & NA & $(+)$ & $(+)$ & / & $\begin{array}{l}\text { Surgery, } \\
\text { CT and } \\
\text { RT }\end{array}$ & $Y$ & \\
\hline 13 & & 39 & M & $\begin{array}{l}\text { Cerebellopontine } \\
\text { angle }\end{array}$ & $\begin{array}{l}\text { Gait imbalance } \\
\text { and bilateral, } \\
\text { lower limb } \\
\text { weakness }\end{array}$ & NA & $(+)$ & / & / & $\begin{array}{l}\text { CT and } \\
\text { RT }\end{array}$ & $\mathrm{N}$ & $\mathrm{N}$ \\
\hline 14 & $\begin{array}{l}\text { Yin WH et al. } \\
(2010)\end{array}$ & 24 & M & $\begin{array}{l}\text { Right } \\
\text { submandibular } \\
\text { gland }\end{array}$ & $\begin{array}{l}\text { Right } \\
\text { submandibular } \\
\text { mass }\end{array}$ & 4 & $(+)$ & $(+)$ & / & $\begin{array}{l}\text { Surgery, } \\
\text { CT and } \\
\text { RT }\end{array}$ & $\mathrm{N}$ & $\mathrm{N}$ \\
\hline 15 & $\begin{array}{l}\text { Santos GP } \\
\text { et al. (2009) }\end{array}$ & 36 & M & $\begin{array}{l}\text { Right } \\
\text { submaxillary } \\
\text { gland }\end{array}$ & $\begin{array}{l}\text { An increase } \\
\text { mass in size } \\
\text { with pain }\end{array}$ & 4 & $(+)$ & $(+)$ & / & $\begin{array}{l}\text { Surgery } \\
\text { and RT }\end{array}$ & $\mathrm{N}$ & $\mathrm{N}$ \\
\hline 16 & $\begin{array}{l}\text { Cho K et al. } \\
(2008)\end{array}$ & 26 & M & $\begin{array}{l}\text { Left } \\
\text { submandibular } \\
\text { gland }\end{array}$ & $\begin{array}{l}\text { A left } \\
\text { submandibular } \\
\text { mass }\end{array}$ & 4 & $(+)$ & / & / & $\begin{array}{l}\text { Surgery, } \\
\text { CT and } \\
\text { RT }\end{array}$ & $Y$ & $\mathrm{Y}, 6$ \\
\hline 17 & $\begin{array}{l}\text { Yoon M et } \\
\text { al. (2005) }\end{array}$ & 32 & M & Left orbit & $\begin{array}{l}\text { Visual } \\
\text { disturbances, } \\
\text { proptosis and } \\
\text { loss of vision }\end{array}$ & 2.5 & / & $(+)$ & / & $\begin{array}{l}\text { Surgery } \\
\text { and RT }\end{array}$ & $\mathrm{N}$ & $\mathrm{N}$ \\
\hline
\end{tabular}




\begin{tabular}{|c|c|c|c|c|c|c|c|c|c|c|c|c|}
\hline \multirow[t]{2}{*}{$\begin{array}{l}\text { Case } \\
\text { No. }\end{array}$} & \multirow[t]{2}{*}{ Source } & \multirow[t]{2}{*}{ Age(years) } & \multirow[t]{2}{*}{ Sex } & \multirow[t]{2}{*}{ Location } & \multirow[t]{2}{*}{ Symptom } & \multirow[t]{2}{*}{$\begin{array}{l}\text { Size } \\
(\mathrm{cm})\end{array}$} & \multicolumn{2}{|c|}{$\begin{array}{l}\text { EWSR1- } \\
\text { WT1 }\end{array}$} & \multirow[t]{2}{*}{$\begin{array}{l}\text { WT1 } \\
\text { (IHC) }\end{array}$} & \multirow[t]{2}{*}{ Treatment } & \multirow[t]{2}{*}{ Metastasis } & \multirow{2}{*}{$\begin{array}{l}\text { Recurrence } \\
\text { (months) }\end{array}$} \\
\hline & & & & & & & $\begin{array}{l}\text { RT- } \\
\text { PCR }\end{array}$ & FISH & & & & \\
\hline 18 & $\begin{array}{l}\text { Lae ME et } \\
\text { al. (2002) }\end{array}$ & 21 & $\mathrm{~F}$ & $\begin{array}{l}\text { Bilateral } \\
\text { ethmoidal } \\
\text { sinuses }\end{array}$ & $\begin{array}{l}\text { Chronic } \\
\text { sinusitis }\end{array}$ & 8 & $(+)$ & $(+)$ & $(+)$ & $\begin{array}{l}\text { Surgery, } \\
\text { CT and } \\
\text { RT }\end{array}$ & $\mathrm{N}$ & $\mathrm{N}$ \\
\hline 19 & & 27 & M & $\begin{array}{l}\text { Scalp soft } \\
\text { tissues, bone } \\
\text { marrow } \\
\text { involvement }\end{array}$ & $\begin{array}{l}\text { Weight loss } \\
\text { and headache }\end{array}$ & NA & / & / & $(+)$ & $\begin{array}{l}\text { Surgery } \\
\text { and CT }\end{array}$ & $\mathrm{N}$ & $\mathrm{N}$ \\
\hline 20 & $\begin{array}{l}\text { Hill DA et al. } \\
(2000)\end{array}$ & 5 & $M$ & Parotid & l & NA & $(+)$ & $(+)$ & $(+)$ & NA & NA & NA \\
\hline 21 & $\begin{array}{l}\text { Wolf AN et } \\
\text { al. (1999) }\end{array}$ & 23 & $M$ & Left parotid & $\begin{array}{l}\text { A slowly } \\
\text { growing mass }\end{array}$ & 5 & $(+)$ & l & / & $\begin{array}{l}\text { Surgery, } \\
\text { CT and } \\
\text { RT }\end{array}$ & $\mathrm{N}$ & $\mathrm{N}$ \\
\hline 22 & $\begin{array}{l}\text { Tison V et } \\
\text { al. (1996) }\end{array}$ & 24 & $M$ & $\begin{array}{l}\text { Left posterior } \\
\text { cranial fossa }\end{array}$ & $\begin{array}{l}\text { Headache, } \\
\text { vomiting, } \\
\text { vertigo and } \\
\text { impaired } \\
\text { hearing }\end{array}$ & 4 & $(+)$ & / & / & $\begin{array}{l}\text { Surgery, } \\
\text { CT and } \\
\text { RT }\end{array}$ & $\mathrm{N}$ & $\mathrm{N}$ \\
\hline 23 & $\begin{array}{l}\text { Current } \\
\text { cases, case } \\
1\end{array}$ & 36 & $M$ & Right orbit & $\begin{array}{l}\text { Vision decline } \\
\text { and difficulty } \\
\text { in opening the } \\
\text { right eye }\end{array}$ & 2.4 & I & $(+)$ & $(-)$ & $\begin{array}{l}\text { Surgery, } \\
\text { CT and } \\
\text { RT }\end{array}$ & $\mathrm{N}$ & $\mathrm{N}$ \\
\hline 24 & $\begin{array}{l}\text { Current } \\
\text { cases, } \\
\text { case } 2\end{array}$ & 30 & M & $\begin{array}{l}\text { Left } \\
\text { submandibular } \\
\text { gland }\end{array}$ & $\begin{array}{l}\text { A left } \\
\text { submandibular } \\
\text { gland mass }\end{array}$ & $3.8,1$ & / & $(+)$ & $(-)$ & $\begin{array}{l}\text { Surgery } \\
\text { and CT }\end{array}$ & Y & $\mathrm{N}$ \\
\hline 25 & $\begin{array}{l}\text { Current } \\
\text { cases, case } \\
3\end{array}$ & 17 & M & $\begin{array}{l}\text { Left } \\
\text { submandibular } \\
\text { gland }\end{array}$ & $\begin{array}{l}\text { A slowly } \\
\text { enlarging and } \\
\text { painless mass }\end{array}$ & 2.5 & / & $(+)$ & / & $\begin{array}{l}\text { Surgery } \\
\text { and CT }\end{array}$ & $\mathrm{N}$ & $\mathrm{N}$ \\
\hline
\end{tabular}

\section{Figures}




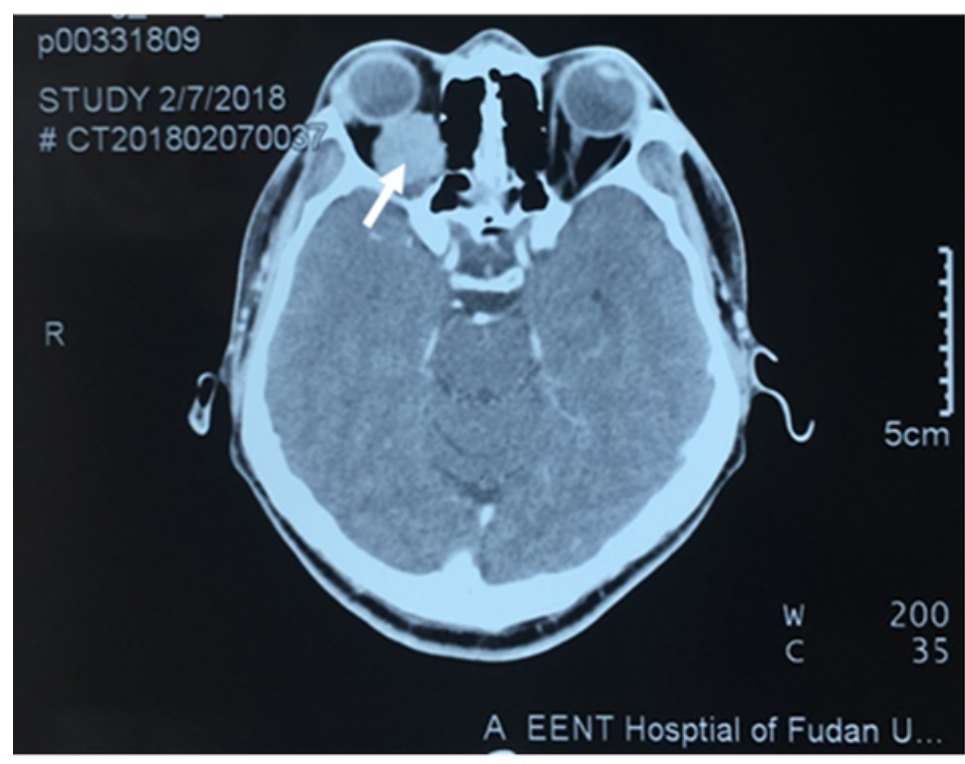

A

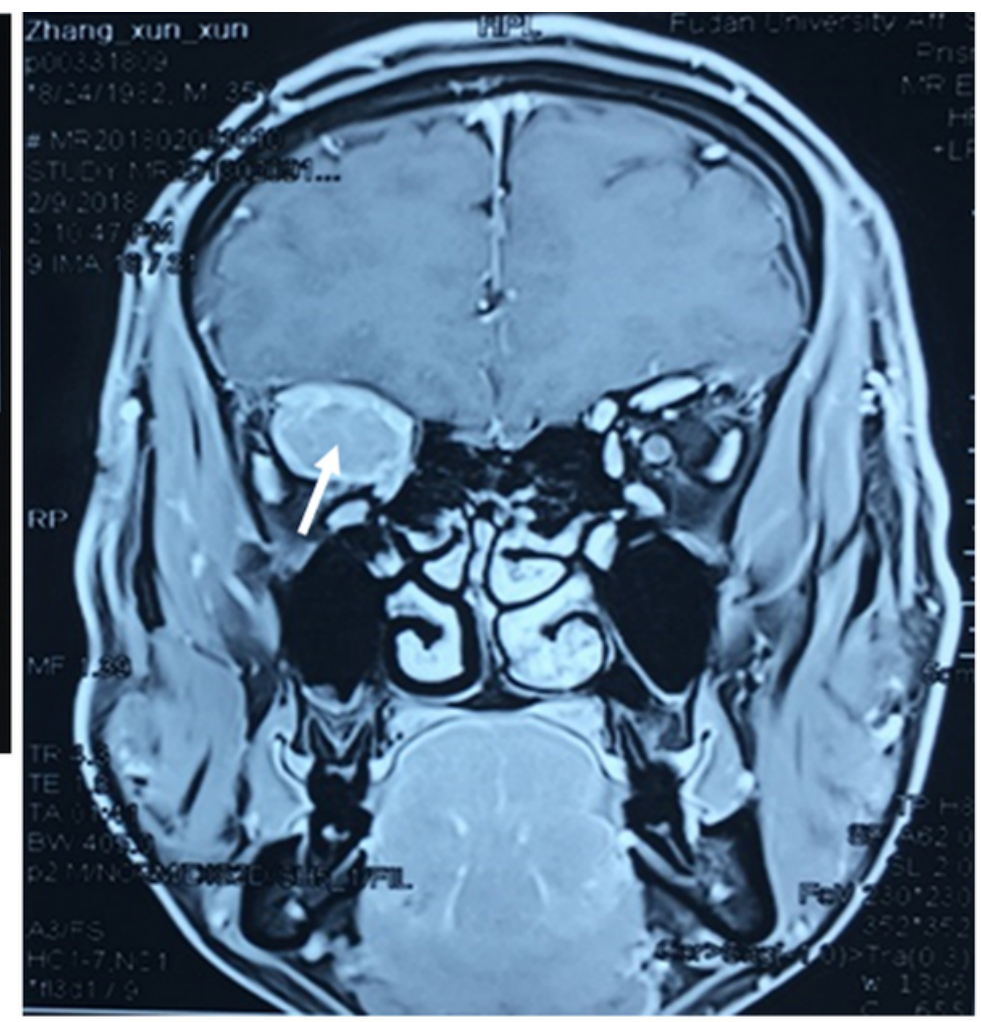

B

Figure 1

Imaging features of DSRCT (case 1). A CT scan showed an ovoid, well-circumscribed soft tissue mass of the right orbital roof, with slightly enhancement (a). MRI revealed a solid heterogeneous mass in the right orbital roof (b).

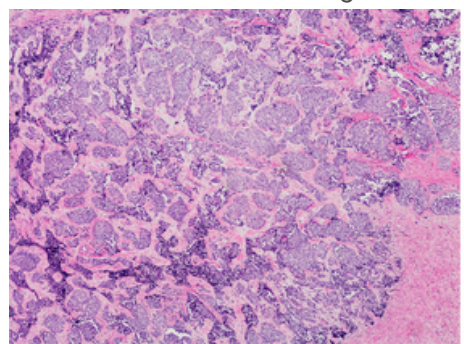

A

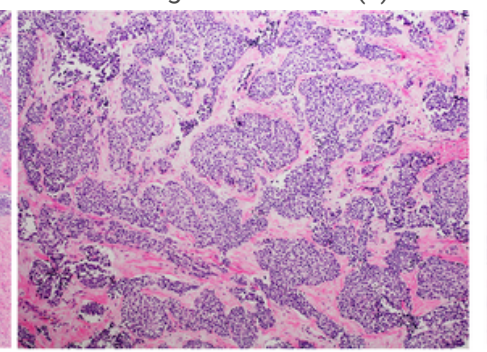

B

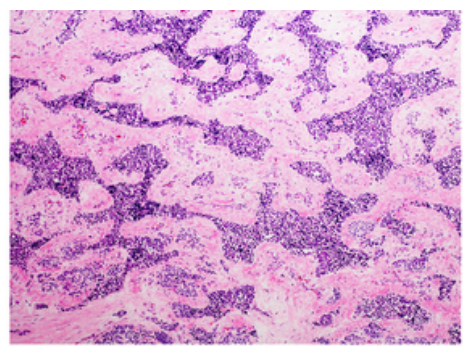

c

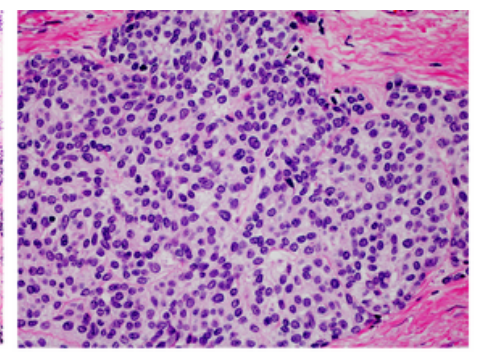

D

\section{Figure 2}

Histological features of DSRCT. Small round cells embedded in abundant desmoplastic stroma (a). The tumor cells were arranged in small clumps, large nests(b), trabeculas or cord-like pattern(c) embedded in abundant desmoplastic stroma. Note hyperchromatic nuclei with scant pale eosinophilic cytoplasm and indistinct margins (d).

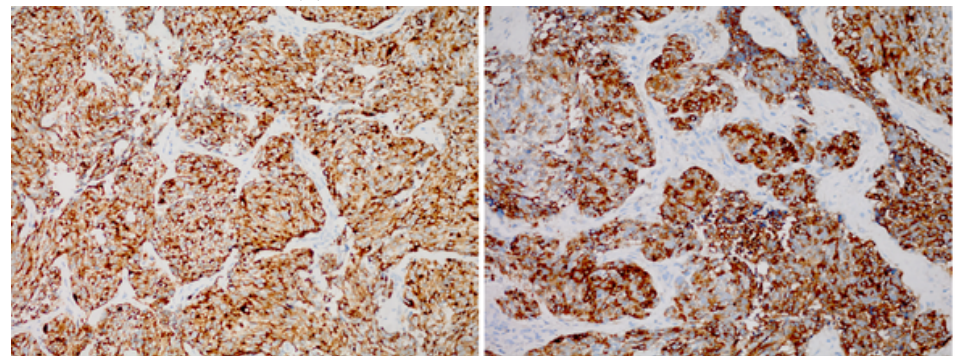

A
B

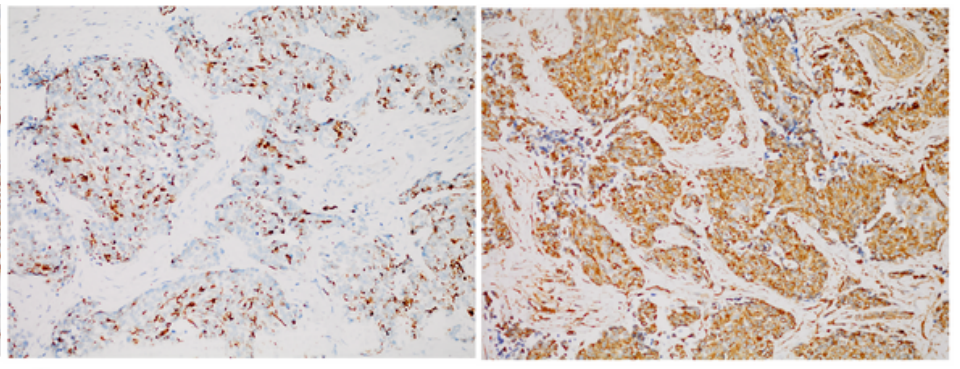

C
D

Figure 3 
Immunohistochemical features of DSRCT. The tumor cells showed diffuse and strong positivity for AE1/AE3 (a) and EMA (b). Desmin (c) and vimentin (d) showed a paranuclear cytoplasmic dot-like immunostaining.
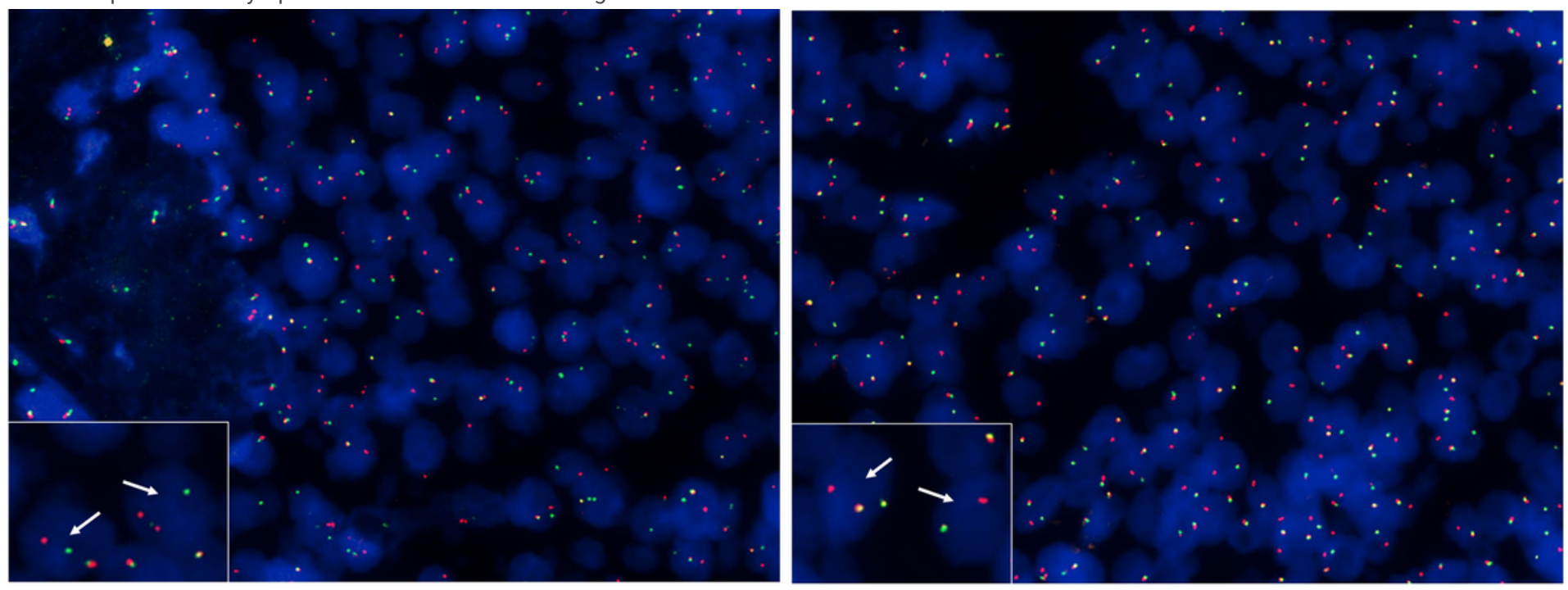

A

B

Figure 4

Molecular features of DSRCT. FISH assay displayed the presence of EWSR1 (a) and WT1 rearrangements (b). 